\title{
A Retrospective Meta-analysis of Semantic-Spatial Comparison of Persian and English Orthographic Systems
}

\author{
Kazem Barzegar $^{*}$, Somayeh Barzegar ${ }^{2}$ \\ ${ }^{1}$ English Language Department, School of Medicine, Shahid Sadoughi University of Medical Sciences, Yazd, Iran \\ ${ }^{2}$ Islamic Azad University, Yazd Branch, Yazd, Iran \\ Email: ${ }^{1}$ farzadbavanati1350@gmail.com, ${ }^{2}$ somayehbarzegar61@gmail.com
}

\begin{abstract}
In this retrospective meta-analysis of the semantic-spatial comparison of the Persian and English orthographic systems, 32 Persian scholarly articles and their English equivalents were compared for number of words, number of pages, number of characters, and number of lines as variables. Non-scholarly papers were excluded from the study. Data were gleaned by word count capability of Microsoft word processor. It was concluded that the English orthographic system can express more semantic content using a smaller number of words; however, considering a given semantic content, the Persian orthographic system can express the same semantic content in less pages, smaller number of characters, and smaller number of lines. So, on the whole, the Persian orthographic system is more economic and cost-effective with respect to the number of pages, characters, and lines compared to the English writing system. Since the translations were performed by only one translator, care should be exercised in generalizing the findings to papers of other academic majors. Our findings also led to the development of the following formula for predicting the translation charges of scholarly papers:

Charge of Persian-to-English translation $\approx$ number of Persian lines $\times 1.35 \times$ charge per line
\end{abstract}

Keywords: Persian, English, orthographic system, alphabets, lexeme

\section{Introduction}

Human language first emerged in the spoken form and survived for thousands of years without any writing system. According to Venezky (1967), English orthography is the system of conventional rules of writing which are applied to represent spoken English in the written from. It was invented because human beings needed to record their spoken words for transmission to those who were not present there at the time of emission of the utterances. As Van Assche et al. (2013) put it, written symbols allow readers to connect spelling to sounds and sounds to meaning. Moreover, the orthographic systems of most languages round the globe have a broad degree of standardization and English orthographic system is not an exception. Unfortunately, there is no exact one-to-one correspondence between the written letters and spoken sounds in English, though some languages enjoy high degrees of such a correspondence. Additionally, there are multiple ways to spell nearly every phoneme, i.e., smallest meaningful unit, in English. On the other hand, most English letters have multiple pronunciations depending on where they occur in a word and also the context. According to Horton (2015), the situation is so chaotic that numerous orthographic mistakes are common even among indigenous speakers of English. This may be mainly attributed to the large number of cognates and words borrowed from many other languages during the evolutionary history of this language. Khansir and Tajeri (2015) assert that this long history has passed without successful attempts at fully-fledged spelling reforms. It is stated in Encyclopædia Britannica (2010) that the major portion of the spelling conventions in Modern English era were distilled from the phonetic spelling of a variety of Middle English. These conventions do not usually mirror the phonemic alterations which have emerged since the late $15^{\text {th }}$ century, i.e., variations like those in the Great Vowel Shift. Fortunately, the orthographic system of English is consistent around the world as this is an international language and in spite of the various English dialects used in different countries and within different parts of the same country, only mild changes are observed in English writing symbols. Indeed, today the most well-known variations are the British and American Spelling systems with minor differences. This general uniformity of spellings 
facilitates international communication; nevertheless, it adds to the discrepancy between the way English is written and spoken in any given location.

The Persian alphabet or Perso-Arabic alphabet is a modified version of the Arabic script which is used for writing the Persian language, the major language spoken in Iran. As Mirdehghan (2010) says, the writing systems of Persian, Urdu, and Pashto draw from a common script, i.e., Arabic, with adaptations to represent sounds specific to each language. Persian is also spoken in Afghanistan, and is the main language in Tajikestan, a former central Asian republic of the former Soviet Union. However, according to Baluch (2005), the Persian spoken in these countries and the writing system used to transcribe the spoken language, especially in Tajikistan, have been influenced by local factors and borrowed words. The Persian script has in common many characteristics with other systems which are founded on the Arabic script. The system is an abjad, i.e., vowels, specifically short vowels, are not shown in writing. The writing direction is exclusively right to left. Moreover, the script uses cursive writing, i.e., most letters in a word are connected to each other and when they are typed, the word processor automatically merges adjacent letter forms. Yet, some Persian compounds do not join and the Persian script adds four extra letters to the 28 letters for a total of 32 characters. According to Lapidus (2002, 2012), the substitution of the Pahlavi script with the Persian script to write the Persian language was accomplished by the Tahirid dynasty in $9^{\text {th }}$ century. Jabbari et al. (2013) postulate that some examples of letter/sound mismatches exist in the orthographic system of both languages; however, those of English are more complex than Persian.

This paper was an attempt to do a semantic-spatial comparison of the orthographic systems of English and Persian using the semantic approach to determine the degree of efficacy and costeffectiveness of the two systems in expressing meaning. In so doing, each lexeme was considered as a semantic unit. So, this study answers the following questions: 1. Which orthographic system, English or Persian, uses a smaller number of pages to express the same semantic content?, 2. Which orthographic system, English or Persian, uses a smaller number of lexemes to express the same semantic content?, 3. Which orthographic system, English or Persian, uses a smaller number of characters with no spaces to express the same semantic content?, and 4. Which orthographic system, English or Persian, uses a smaller number of text lines to express the same semantic content?

\section{Methodology}

\subsection{Materials \& Methods}

This was a retrospective meta-analysis of the semantic-spatial comparison of the Persian and English orthographic systems. To do so, the following steps were taken: a) The researcher collected the Microsoft word files of all the Persian scholarly articles and abstracts translated by him into English for publication in ISI journals during the past five years, i.e., 2012-2017. The non-scholarly manuscripts were excluded from the study. b) He also collected all the corresponding Microsoft word files of the English articles and abstracts, i.e., retrospective data. c) They were classified according to the subjects of the articles that covered 16 areas as shown in Table 1. d) There were a total of 113 Persian articles, yet for more simplicity and accuracy, the researcher selected only 2 articles in each scientific field. So, there were 32 Persian and 32 corresponding English articles. The goal of selection of various fields was to increase data diversification leading to more generalizability of the findings. e) For convenience, the files of the Persian and English articles were named similarly and systematically, for example: "Diabetes English.doc" and "Diabetes Persian.doc" so that there was a nice alphabetical arrangement of the files. f) Since the researcher was concerned just with the texts of the articles, all the tables, graphs, pictures and figures were removed from both Persian and English articles. Moreover, textboxes, footnotes, and endnotes were excluded by ticking the related box in Microsoft Word file. References were also excluded to prevent data confounding. g) To remove any empty spaces in the word files, all the empty lines and empty spaces were removed by placing just one character space between any two successive sentences. $\mathrm{h}$ ) The files of both English and Persian articles were saved using the following settings: Font type: Times New Roman, Font size: 14, Line spacing: 1.5, No space before and after lines, Paper size: A4, Margins: top: $2.5 \mathrm{~cm}$, bottom: $2.5 \mathrm{~cm}$, left: $2.5 \mathrm{~cm}$, right: $2.5 \mathrm{~cm}$. i) The word counts of all the files as variables of 
the study were obtained using Microsoft word count including: pages, words, characters with no spaces, and lines. The data were imported to tables.

Table 1. Data of 16 subject areas covered by the Persian and their equivalent English articles

\begin{tabular}{c|l|c|c|c}
\hline No. & Article field & Number of Persian articles & Number of English articles & Total \\
\hline 1 & Biochemistry & 2 & 2 & \\
2 & Cardiovascular diseases & 2 & 2 & \\
3 & Dentistry & 2 & 2 & \\
4 & Education & 2 & 2 & \\
5 & Health & 2 & 2 & \\
6 & History & 2 & 2 & \\
7 & Immunology & 2 & 2 & \\
8 & Library sciences & 2 & 2 & \\
9 & Literature & 2 & 2 & \\
10 & Medical ethics & 2 & 2 & \\
11 & Microbiology & 2 & 2 & \\
12 & Nursing \& midwifery & 2 & 2 & \\
13 & Ophthalmalogy & 2 & 2 & \\
14 & Pharmacology & 2 & 2 & \\
15 & Physiology & 2 & 2 & \\
16 & Psychology & 2 & 2 & \\
\hline
\end{tabular}

\subsection{Data Collection}

The required data of the Persian articles files including pages, words, characters with no spaces, and lines were obtained using Microsoft word count and imported to Table 2.

Table 2. Statistical data of 32 Persian articles files

\begin{tabular}{|c|c|c|c|c|c|}
\hline $\begin{array}{l}\text { Article } \\
\text { No. }\end{array}$ & Persian title & Pages & Words & $\begin{array}{c}\text { Characters } \\
\text { with no } \\
\text { spaces } \\
\end{array}$ & Lines \\
\hline 1 & آسيب كبدى ناشى از استرس اكسيداتيو & 3 & 1157 & 4727 & 74 \\
\hline 2 & شده توسط اثر كوركومين بربيان Rac1-GTP,Rac1 و NOX1 مر فر فيبروز كبدى القاء & 2 & 775 & 3604 & 55 \\
\hline 3 & مقايسه تاثيرتزريق ايبيدور ال دكز امتازون وتريامسينولون در درمان كمردرد & 7 & 2953 & 12297 & 188 \\
\hline 4 & بيمار بـى ناثير كاربرد بِماد املا و كيسه يخ بر درد ناثشى از ورود سوزن هاى عروقى در & 9 & 3815 & 15445 & 236 \\
\hline 5 & قلب ورسى ارزش تشخيصى سنى هاى بالي؟ى دندان در تشخيص بيمارى هاى ايسكيك & 10 & 3978 & 17037 & 272 \\
\hline 6 & 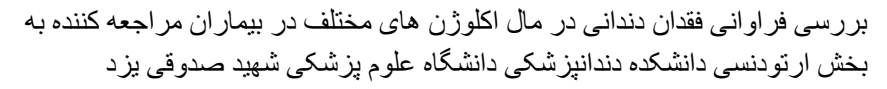 & 1 & 321 & 1372 & 22 \\
\hline 7 & 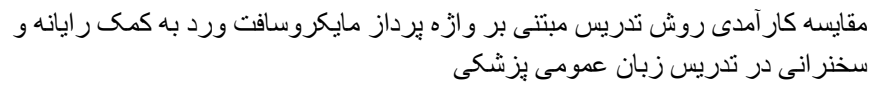 & 7 & 4251 & 17334 & 293 \\
\hline 8 & مقايسه نمره بايان ترم وخود ارزيابى دانشجويان برستارى دردرس انكل شناسى & 2 & 448 & 1873 & 32 \\
\hline 9 & بركلتي ارتباط بين شاخص دهاي فيزيكي كيفيت زندخي مرتبط با سلامت با اختلالات & 8 & 2774 & 12832 & 196 \\
\hline 10 & 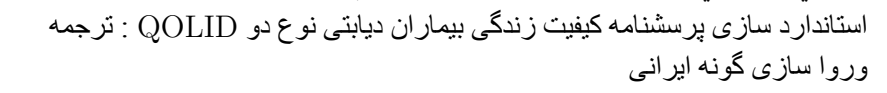 & 8 & 3348 & 13473 & 208 \\
\hline 11 & تثكيل سلسله صفويه & 1 & 368 & 1589 & 23 \\
\hline 12 & جهانى شدن بيدارى انسانى- اسلامى و جهانى سازى با هويت اسلام ناب محمدى(ص) & 2 & 755 & 3243 & 50 \\
\hline 13 & 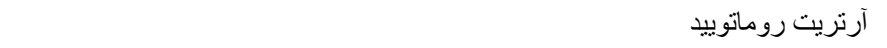 & 9 & 3769 & 16443 & 246 \\
\hline
\end{tabular}




\begin{tabular}{|c|c|c|c|c|c|}
\hline $\begin{array}{l}\text { Article } \\
\text { No. }\end{array}$ & Persian title & Pages & Words & $\begin{array}{l}\text { Characters } \\
\text { with no } \\
\text { spaces }\end{array}$ & Lines \\
\hline 14 & سل & 7 & 2879 & 11735 & 190 \\
\hline 15 & كاربرد TRIZدر مرجع نويسي الكترونيكي & 9 & 3367 & 14864 & 278 \\
\hline 16 & حكيم سنايى غزنوى & 1 & 210 & 862 & 15 \\
\hline 17 & عطار و تفكر تجلى & 1 & 225 & 881 & 14 \\
\hline 18 & صور خيال با رويكرد مجاز در غزليات سنايى & 1 & 196 & 829 & 15 \\
\hline 19 & جالثهاى اخلاقى طب اعتياد در ايران & 2 & 557 & 2422 & 43 \\
\hline 20 & بررسى نسبت رضايت اخلاقى وحقوقى بيمار ان در ايران & 1 & 326 & 1574 & 25 \\
\hline 21 & وبكومايسين جدا شده از هاو المونه هاى مقاومت آنتى بيوتيكى انتروكوى هاى مقاوم به & 1 & 339 & 1479 & 24 \\
\hline 22 & اسينتوباكتر بومانى & 3 & 1186 & 5884 & 79 \\
\hline 23 & برداشتن رحم & 7 & 2231 & 10298 & 163 \\
\hline 24 & شايستحى اخلاقى رهبر ان برستارى: با رويكرد كيفى مبتنى بر تحليل محتو ا & 17 & 6653 & 28572 & 465 \\
\hline 25 & بررسلاكس نقش تشت سنتيكر افى مجارى اشكى در تشخيص انسداد مجارى اشكى با & 5 & 2053 & 8192 & 125 \\
\hline 26 & بررسى علل ونتايج نخليه جشم در بيمارستان شهيدصدوقى يزد & 4 & 1570 & 6907 & 108 \\
\hline 27 & برسى انكيزه و ميزان رضايت مر اجعه كنندكان جهت انجام حجامت در شهر يزد - & 5 & 1757 & 7657 & 119 \\
\hline 28 & 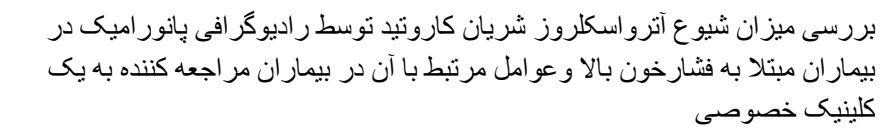 & 5 & 2007 & 8984 & 135 \\
\hline 29 & وارفارين ميزان بيان نسبى MicroRNA-133a در بيمار ان دريافت كننده ى & 5 & 2654 & 11715 & 181 \\
\hline 30 & ابيكمى در موش ها به عنو ان يك بِروتثين سيكنال دهنده در مرحله بعدى بيش شرطى سازى & 11 & 4357 & 19594 & 296 \\
\hline 31 & 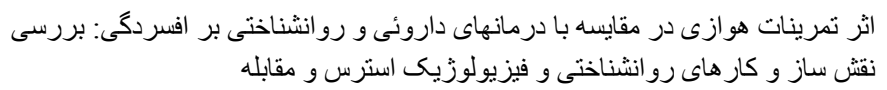 & 13 & 5384 & 23158 & 354 \\
\hline 32 & كار آمدى رفتاردرمانى كفتارى در سلامت رو انى بيمار ان ديابتى & 9 & 3425 & 13979 & 244 \\
\hline
\end{tabular}

Moreover, the required data of the English scholarly articles files as variables including pages, words, characters with no spaces, and lines were obtained using Microsoft word count and imported to Table 3.

Table 3. Statistical data of 32 English articles files

\begin{tabular}{|c|c|c|c|c|c|}
\hline $\begin{array}{l}\text { Article } \\
\text { Code }\end{array}$ & English title & Pages & Words & $\begin{array}{l}\text { Characters } \\
\text { with no } \\
\text { spaces }\end{array}$ & Lines \\
\hline 1 & Hepatic injury induced by oxidative stress & 4 & 1055 & 5803 & 92 \\
\hline 2 & $\begin{array}{l}\text { Study of the effect of Curcumin on the expression of Rac1, } \\
\text { Rac1-GTP, and NOX1 in hepatic fibrosis induced by ligation of } \\
\text { bile duct }\end{array}$ & 3 & 829 & 4517 & 72 \\
\hline 3 & $\begin{array}{l}\text { Comparison of the Effect of Epidural Injection of } \\
\text { Dexamethasone and Triamcinolone in treating Low Back Pain }\end{array}$ & 9 & 2783 & 14769 & 250 \\
\hline 4 & $\begin{array}{l}\text { Study of the Effect of EMLA Cream and Ice Pack on the Pain } \\
\text { of Vascular Needles Insertion in Hemodialysis Patients }\end{array}$ & 11 & 3385 & 18308 & 297 \\
\hline 5 & $\begin{array}{l}\text { Study of the Diagnostic Value of Dental Pulp Stones in the } \\
\text { Diagnosis of Ischemic Cardiovascular Diseases }\end{array}$ & 13 & 3902 & 20872 & 338 \\
\hline 6 & $\begin{array}{l}\text { Frequency of Hypodontia in Various Malocclusions in Patients } \\
\text { Presenting to Orthodontics Ward of Yazd Shahid Sadoughi } \\
\text { University of Medical Sciences }\end{array}$ & 1 & 272 & 1556 & 27 \\
\hline
\end{tabular}




\begin{tabular}{|c|c|c|c|c|c|}
\hline $\begin{array}{l}\text { Article } \\
\text { Code }\end{array}$ & English title & Pages & Words & $\begin{array}{c}\text { Characters } \\
\text { with no } \\
\text { spaces }\end{array}$ & Lines \\
\hline 7 & $\begin{array}{l}\text { A Study of the Effectiveness of Microsoft Word-Based } \\
\text { Computer Assisted Instruction Method vs. the Traditional } \\
\text { Lecturing Method in Teaching English for the Students of } \\
\text { Medicine }\end{array}$ & 12 & 3649 & 19382 & 320 \\
\hline 8 & $\begin{array}{l}\text { Comparison of final exam scores and nursing students' self- } \\
\text { assessment in medical parasitology course }\end{array}$ & 2 & 384 & 2143 & 42 \\
\hline 9 & $\begin{array}{l}\text { Survey of the Relationship Between Health-Related Physical } \\
\text { Indices of Life Quality and Musculoskeletal Symptoms in Saipa } \\
\text { Auto Assembly Workers }\end{array}$ & 9 & 2729 & 15487 & 244 \\
\hline 10 & $\begin{array}{l}\text { Standardization of the QOLID: Translation and Validation of } \\
\text { the Iranian Version }\end{array}$ & 10 & 3117 & 17199 & 279 \\
\hline 11 & Formation of Safavid dynasty & 2 & 398 & 2136 & 33 \\
\hline 12 & $\begin{array}{l}\text { Globalization, Humanistic-Islamic Awakening, and } \\
\text { Globalization with the Pure Mohammadan Islam Nature }\end{array}$ & 3 & 772 & 4387 & 73 \\
\hline 13 & Rheumatoid arthritis & 11 & 3417 & 17952 & 292 \\
\hline 14 & Tuberculosis & 9 & 2609 & 14301 & 234 \\
\hline 15 & The Use of TRIZ in Electronic Reference Services & 14 & 3601 & 19965 & 410 \\
\hline 16 & Hakim Sanayee Qaznavi & 1 & 253 & 1446 & 25 \\
\hline 17 & Attar and "manifestation" thought & 1.1 & 302 & 1672 & 30 \\
\hline 18 & Imagery in Sanayee's Lyrics with a Metaphoric Approach & 1 & 217 & 1215 & 26 \\
\hline 19 & The Ethical Challenges of Addiction Medicine in Iran & 2 & 598 & 3309 & 54 \\
\hline 20 & $\begin{array}{l}\text { Study of Proportion of Iranian Patients' Ethical and Legal } \\
\text { Satisfaction Level }\end{array}$ & 1.6 & 439 & 2612 & 43 \\
\hline 21 & $\begin{array}{l}\text { Prevalence and antibiotic resistance of Enterococci species } \\
\text { isolated from clinical sample }\end{array}$ & 1 & 259 & 1501 & 25 \\
\hline 22 & Acinetobacter Baumannii & 4 & 1213 & 6931 & 106 \\
\hline 23 & Hysterectomy & 9 & 2402 & 13234 & 222 \\
\hline 24 & $\begin{array}{l}\text { Ethical Competency of Nursing Leaders: A Qualitative } \\
\text { Approach Based on Content Analysis }\end{array}$ & 22 & 6458 & 36214 & 615 \\
\hline 25 & $\begin{array}{l}\text { Study of the Role of Dacryocintigraphy of Lachrymal Ducts in } \\
\text { Diagnosing Lachrymal Ducts with Negative Reflux }\end{array}$ & 7 & 1852 & 10682 & 177 \\
\hline 26 & $\begin{array}{l}\text { A Study of the Causes and Results of Enucleation at Yazd } \\
\text { Shahid Sadoughi Hospital }\end{array}$ & 6 & 1578 & 8623 & 137 \\
\hline 27 & $\begin{array}{l}\text { Study of Motivation and Satisfaction Rate in Patients } \\
\text { Presenting for Blood-letting in Yazd in } 2014\end{array}$ & 6 & 1901 & 11023 & 174 \\
\hline 28 & $\begin{array}{l}\text { Frequency Distribution of Carotid Artery Atherosclerosis and } \\
\text { the Related Factors using Panoramic Radiography in } \\
\text { Hypertensive Patients Presenting to a Private Clinic }\end{array}$ & 8 & 2098 & 12245 & 201 \\
\hline 29 & $\begin{array}{l}\text { Investigation of Micro RNA-133a Relative Expression in } \\
\text { Patients Receiving Warfarin }\end{array}$ & 8.2 & 2613 & 14612 & 241 \\
\hline 30 & $\begin{array}{l}\text { SIRTUIN1 as a Signaling Protein in the Late Phase of Ischemia } \\
\text { Preconditioning in Rats }\end{array}$ & 14 & 4438 & 23574 & 386 \\
\hline 31 & $\begin{array}{l}\text { The Effect of Aerobic Exercises Compared to Medical and } \\
\text { Psychological Treatment on Depression: Investigation of Psycho } \\
\text { Physiological Mechanisms }\end{array}$ & 15 & 4564 & 26304 & 435 \\
\hline 32 & $\begin{array}{l}\text { The effectiveness of dialectical behavioral therapy on } \\
\text { psychological well-being in patients with diabetes }\end{array}$ & 11 & 2981 & 17569 & 305 \\
\hline
\end{tabular}

\section{Results}

On the basis of Microsoft word count data given in Table 3 and Table 4, the proportions of English (E.) 
to Persian (P.) pages, the proportions of English to Persian words, the proportions of English to Persian characters with no spaces, and the proportions of English to Persian lines of both English and Persian articles and abstracts were estimated using professional calculator and tabulated in Table 4 . The mean proportions are also calculated and presented in this table.

Table 4. Proportions of E. to P. pages, words, characters, and lines of the articles

\begin{tabular}{|c|c|c|c|c|}
\hline Article code & $\begin{array}{c}\text { Proportion of E. } \\
\text { to P. pages }\end{array}$ & $\begin{array}{l}\text { Proportion of E. } \\
\text { to P. words }\end{array}$ & $\begin{array}{l}\text { Proportion of E. } \\
\text { to P. characters }\end{array}$ & $\begin{array}{c}\text { Proportion of E. } \\
\text { to P. lines }\end{array}$ \\
\hline 1 & 1.33 & 0.91 & 1.22 & 1.24 \\
\hline 2 & 1.5 & 1.06 & 1.14 & 1.30 \\
\hline 3 & 1.28 & 0.94 & 1.20 & 1.32 \\
\hline 4 & 1.22 & 0.88 & 1.18 & 1.25 \\
\hline 5 & 1.30 & 0.98 & 1.22 & 1.24 \\
\hline 6 & 1 & 0.84 & 1.13 & 1.22 \\
\hline 7 & 1.7 & 0.85 & 1.11 & 1.09 \\
\hline 8 & 1 & 0.85 & 1.14 & 1.31 \\
\hline 9 & 1.12 & 0.98 & 1.20 & 1.24 \\
\hline 10 & 1.25 & 0.93 & 1.27 & 1.34 \\
\hline 11 & 1.1 & 1.08 & 1.34 & 1.43 \\
\hline 12 & 1.5 & 1.02 & 1.35 & 1.46 \\
\hline 13 & 1.22 & 0.90 & 1.09 & 1.18 \\
\hline 14 & 1.28 & 0.90 & 1.21 & 1.23 \\
\hline 15 & 1.55 & 1.07 & 1.34 & 1.47 \\
\hline 16 & 1 & 1.20 & 1.67 & 1.66 \\
\hline 17 & 1.1 & 1.34 & 1.89 & 2.14 \\
\hline 18 & 1 & 1.10 & 1.46 & 1.73 \\
\hline 19 & 1 & 1.07 & 1.36 & 1.25 \\
\hline 20 & 1.6 & 1.34 & 1.65 & 1.72 \\
\hline 21 & 1 & 0.76 & 1.01 & 1.04 \\
\hline 22 & 1.33 & 1.02 & 1.17 & 1.34 \\
\hline 23 & 1.28 & 1.07 & 1.28 & 1.36 \\
\hline 24 & 1.29 & 0.97 & 1.26 & 1.32 \\
\hline 25 & 1.4 & 0.90 & 1.30 & 1.41 \\
\hline 26 & 1.5 & 1 & 1.24 & 1.26 \\
\hline 27 & 1.2 & 1.08 & 1.43 & 1.46 \\
\hline 28 & 1.6 & 0.52 & 1.36 & 1.48 \\
\hline 29 & 1.64 & 0.98 & 1.24 & 1.33 \\
\hline 30 & 1.27 & 1.01 & 1.20 & 1.30 \\
\hline 31 & 1.15 & 0.84 & 1.13 & 1.22 \\
\hline 32 & 1.22 & 0.87 & 1.25 & 1.25 \\
\hline Mean Proportion & 1.27 & 0.97 & 1.28 & 1.35 \\
\hline
\end{tabular}

Other descriptive statistics such as maximum and minimum of proportions are displayed in Table 5.

Table 5. Descriptive statistics of the four variables under study

\begin{tabular}{lcc}
\hline \multicolumn{1}{c}{ Variables } & Maximum & Minimum \\
\hline Proportion of E. to P. pages & 1.64 & 1 \\
Proportion of E. to P. words & 1.34 & 0.52 \\
Proportion of E. to P. characters & 1.67 & 1.01 \\
Proportion of E. to P. lines & 2.14 & 1.04 \\
\hline
\end{tabular}




\section{Discussion}

Our findings demonstrated interesting points about the variables of the Persian and English files of the articles and abstracts. We found that considering a given semantic content, English uses a smaller number of words to express the same content compared to Persian. As observed in Table 4, the mean proportion of English to Persian words is 0.97 suggesting that, on the average, the semantic content expressed by 1 Persian word can be expressed by 0.97 English words. This means that English can express more meaning with a smaller number of words compared to Persian. So, the English orthographic system is more economic and cost-effective with respect to word count compared to the Persian orthographic system. The fields of the articles were purposively selected diversely in a way as to include various fields to increase the accuracy of results.

However, the mean proportion of E. to P. pages was 1.27 indicating that the Persian orthographic system is more economic and cost-effective than the English one since the semantic content expressed by 1 Persian page of text requires 1.27 English pages to be expressed. Moreover, the mean proportion of E. to $\mathrm{P}$. characters with no spaces was 1.28 indicating that the Persian orthographic system is more economic and cost-effective than the English one since the semantic content expressed by 1 Persian character requires 1.28 English characters to be expressed. Furthermore, the mean proportion of E. to P. lines was 1.35 indicating that the Persian orthographic system is more economic and cost-effective than the English one since the semantic content expressed by 1 Persian line of text requires 1.35 English lines to be expressed.

The cost-effectiveness of the Persian orthographic system over the English one can be attributed to at least two factors. One reason is that the Persian writing system does not represent the short vowels including /æ/, /e/, and / / while English does. This underrepresentation is, of course, a flaw of the Persian writing system because it causes some ambiguity in reading. For example, the Persian word 'كرم' may be read in four different ways with different meanings:

/kerm/ meaning 'worm'

/kæ`ræm/ meaning 'generosity'

/ke`rem/ meaning 'cream'

/kv `rvm/ meaning 'chrome'

The second reason may be attributed to the cursive writing used by the Persian orthographic system. The Persian alphabets ligate and join to reduce space while there are no ligature letters in modern English writing system like /æ/ used in old English.

Furthermore, there are some differences among the proportions with respect to the subject of the articles. As can be observed in Table 4, in the field of microbiology, there are 1.64 pages needed for the English translation for 1 Persian page while there is the need to 1 English page for 1 Persia page in dentistry, for example. Also, the Persian writing system is most economic in the filed of literature as article 17, when translated into English required 2.14 English lines for each Persian line. On the contrary, there is a one-to-one correspondence of lines required by both English and Persian articles in the field of bacteriology.

This work was the first endeavor in this type of comparison. So, there is no work with which to compare these findings. However, other studies have compared other aspects of the orthographic systems. Jabbari et al. (2013) speculated that by receiving education in L1 Persian, with its semi-opaque orthography system, the students would learn the English opaque graphemes better on the mismatches. Nonetheless, they found that both elementary and advanced learners faced difficulty learning English orthography system while they betrayed almost no positive effect from their first language. Taghipour et al. (2016) demonstrated that the Persian language contains much irregularity which is characterized by the complexity measures of L-systems which represent the words and that this irregularity has increased over the temporal evolution of the language. Furthermore, Baluch (2005) emphasized on how literacy acquisition by Persian beginner and skilled readers may be influenced by specific features of Persian orthography which affects cognitive processes involved in the reading of Persian. Finally, Mirdehghan (2011) presented a comparative analysis that can inform computational studies of Persian, Urdu, and Pashto orthography and ease the teaching of reading and writing in these languages, especially among second language learners. 


\section{Conclusion}

Based on the findings of this study, it is concluded that the English orthographic system can express more semantic content using a smaller number of words; however, considering a given semantic content, the Persian orthographic system can express the same semantic content in less pages, smaller number of characters with no spaces, and smaller number of text lines. So, on the whole, the Persian orthographic system is more economic and cost-effective with respect to the number of pages, characters, and lines compared to the English writing system. Also, when a Persian article is translated into English, the number of English lines can be predicted by multiplying the number of Persian lines by 1.35. This would lead to the following formula used in estimating the approximate cost of Persian-to-English translation:

Charge of Persian-to-English translation $\approx$ number of Persian lines $\times 1.35 \times$ charge per line

\subsection{Limitations of the Study}

This study covered only scholarly articles and excluded papers pertaining to other academic majors. Thus, care should be taken in generalizing the findings to papers of other academic fields. Besides, the scholarly manuscripts were translated from Persian into English by only one translator that may lead to translator bias jeopardizing the external validity of the results. Again, generalization of results to new contexts should be carried out with sufficient caution.

\subsection{Suggestion for Further Research}

Future research can specifically focus on this topic with respect to comparison of writing systems of other languages or other features of writing systems.

\section{References}

1. Baluch, Bahman (2005). Persian Orthography and Its Relation to Literacy. https://core.ac.uk/download/pdf/ 19206056.pdf

2. English language. (2010). In Encyclopædia Britannica. Retrieved November 23, 2010, from Encyclopædia Britannica Online.

3. Horton, Helena (2015). Our most commonly misused words and phrases. The Sydney Morning Herald.

4. Jabbari et al. (2013). The Effect of L1 Persian on the Acquisition of English L2 Orthographic System on the Shared Grounds. Iranian Journal of Applied Language Studies, Vol. 6, No. 1, 2014.

5. Khansir, Ali Akbar \& Tajeri, Mojtaba (2015). The relationship between spelling and pronunciation in English language. Language in India, 15 (12): P. 66.

6. Lapidus, Ira M. (2002). A history of Islamic societies. Cambridge University Press. P. 127.

7. Lapidus, Ira M. (2012). Islamic Societies to the nineteenth century: A global history. Cambridge University Press. pp. 256

8. Mirdehghan, Mahinnaz (2010). Persian, Urdu, and Pashto: A comparative orthographic analysis. Writing Systems Research Volume, 2, 2010, Issue 1, Pages 9-23.

9. Taghipour, N. ,H. H. Seyyed Javadi, M. M. Dehshibi, \& A. Adamatzky (2016). On Complexity of Persian Orthography: L-Systems Approach. Complex Systems 25(2):128-156

10. Van Assche, Eva; Duyck, Wouter; Hartsuiker, Robert J. (2013), "Phonological Recoding in Error Detection: A Cross-sectional Study in Beginning Readers of Dutch", PLOS ONE, 8 (12): doi:10.1371/journal.pone.0085111

11. Venezky, Richard L. (1967), "English orthography: Its graphical structure and its relation to sound", Reading Research Quarterly, 2 (3): 75-105, doi: 10.2307/747031 